Myers presented his report on the very numerous anthropometric investigations he has made among the native troops of the Egyptian army, and at the same time described a method of radial craniometry. The skeleton of Cornelius Magrath, the Irish giant, was exhibited, and the subject of giantism was lucidly explained, by Prof. J. D. Cunningham; Prof. A. F Dixon also exhibited a skull modified by acromegaly. Prof. J. Symington exhibited some ancient Irish crania collected by the late John Grattan, of Belfast, and described the methods of cranial investigation adopted by that gentleman ; the president also alluded in eulogistic terms to the acumen of Mr. Grattan, who, though he was engaged in business and had not received a scientific training, yet was in his time in advance of every European craniologist so far as methods were concerned.

Psychology.-Miss A. Amy Bulley read a paper on the psychology of primitive man; while primitive man had no absolute mental deficiency, he "sensed" objects singly and without anything more than a hazy perception of their relation to one another. The results of this deficiency were:-(I) Inability to generalise ; $(2)$ no distinction recognised between essential and non-essential characteristics; (3) imperfect understanding of cause and effect. These imperfections were employed as tests for certain religious ideas that have been attributed to primitive man, such as one supreme God, phallic worship, the ghost theory and the theory of the continuum in religion. Dr. W. Graham's paper on the mental and moral characteristics of the people of Ulster led to a very lively debate which was fortunately free from excess, although the author referred to the increase of insanity due to religious excitement in the north of Ireland. The main valid criticism was the pointing out that the author fell into the common mistake of calling the nonTeutonic element in Ireland "Celtic," thereby entirely ignoring the vastly preponderating Mediterranean strain.

Ethnography.-There were several papers, illustrated with lantern slides, which described certain peoples who had been studied by the lecturers. Dr. W. H. Furness gave an entertaining and instructive discourse on the Nagas, whom he visited with the special purpose of investigating whether they had a connection with any of the interior tribes of Borneo; he came to the conclusion that there was no positive proof for this view. The Lolos and other tribes of western China were dealt with by Mr. A. Henry. A comparison of the Lolo and Mias-tze speech with the Chinese suggests that the tonal monosyllabic languages form a distinct primitive group and are not the result of linguistic degradation; the peculiar script of the Lolos may be due to early Nestorian missionaries; the surnames of the Lolos always signify the name of a tree or animal, which may not be touched. Messrs. Nelson Annandale and H. C. Robinson described the wild and civilised tribes of Malay Peninsula. No distinction could be drawn between the Malays and Siamese of the district between Singora and Jambu ; there is evidence of an admixture of aboriginal blood; the savage tribes are the Semangs, Sakais and Orang Laut Kappir of Trang. The report on the ethnological survey of Canada was presented. The Canadian Committee itself has not yet got beyond the "resolution" stage ; the long report of more than ninety pages is solely the work of the secretary, Mr. C. Hill-Tout, who has investigated, mainly linguistically, the Lower Fraser Indians of British Columbia. The Royal Society of Canada has at last undertaken to prosecute with vigour the important and pressing objects of this committee.

Comparative Religion. - The human souls and ghosts of the Malays of Patani were described by Mr. N. Annandale, as well as the ghosts of inspired magicians, the giving in marriage of the son of such a ghost, and the marriage procession (a cyclone) ; the evolution was traced of a local god from such a ghost. Two papers by the Rev. J. H. Holmes were read by the president. The first described the sacred initiation ceremonies undergone by the lads of the Papuan Guif. The boy is isolated in the "eravo," or club house, until his hair has grown to its full length. His body must not be exposed to the sun, and he is subject to several taboos. The bull-roarer is shown and explained, and masks play a great part in the more important ceremonies. The second paper dealt with the religious ideas of the Elema tribe of the Papuan Gulf. From certain customs and taboos, it is evident the natives were totemic people. but they appear to have partially passed beyond this phase. There are four classes of ghosts- those who have died a natural death, who have been killed in a fight, who have been murdered, and who have been killed by a crocodile. Every family of living things, from man downwards, has its special god or guardian spirit, for whom there is a feeling of respect ; for example, the banana has two gods. The Toaripi or Elema recognise a good and an evil supreme god and a number of subsidiary ones. $\mathrm{Mr}$. F. T. Elworthy exhibited a number of perforated stone amulets from Lincolnshire, Dorset, Somerset, co. Antrim, and southern Italy which are used as prophylactic agents against witchcraft in houses, cattle byres, or in gardens. An important paper on the Lia Fail of Tara and election of kings by augury was communicated by Mr. E. S. Hartland. The famous Lia Fail, or Stone of Destiny, often, but erroneously, identified with the Coronation Stone, was a stone on which were enchantments, for it used to roar under the person who had the best right to obtain the sovereignty of Ireland at the time the men of Ireland were in assembly at Tara to choose a king over them. It was thus an oracle, and the choice of king was made by the augury which it gave. Kingship was something more than human; it was thus necessary to ascertain the will of the gods. Other examples from diverse times and places were given as proo's of the widespread character of these customs.

Survivals.-Mr. E. Lovett discoursed in an interesting manner on tallies; these are records kept by cutting notches in sticks of wood, and are a survival of probably the earliest appliance of a commercial nature made by man. There are two varieties: (I) the contract tally, formed by a stick split through the notches, and (2) the simple or memorandum tally, a single notched slip of wood. The simple or folk tally has survived the complex form as elaborated in the banker's and exchequer tallies. Numerous modern examples were exhibited. Mr. Hartland exhibited two wooden "swords" formerly worn as professional emblems by medical practitioners in Japan; one represented a bean pod, and the other was a rough piece of wood.

Museums. - On the last morning, a very interesting discussion on the classification and arrangement of exhibits in anthropological museums was started by the reading, by the recorder, of a very suggestive paper by Dr. W. H. Holmes, of the U.S. National Museum. The chief methods of arrangement are the ethnographical on a geographical basis, and the evolutionary and distributionary. It was generally agreed that no hard and fast rule could be laid down, but that it was desirable that every museum should develop along its own lines, subject to a controlling idea along one of these chief directions. It was held essential that museums should be liberally labelled, and rendered at the same time instructive and interesting; more attention should be paid to these points, as the success of a museum depends upon the interest that it awakens.

Classification. - The business of the Section terminated with a discussion of the classification of the subject-matter of anthropology; this was opened by Mr. E. N. Fallaize with a suggested scheme which was offered for future consideration.

A popular feature of the Section was the interesting museum mainly of local archæology and ethnographic survivals which, thanks to the courtesy of Prof. Symington, were exhibited in the dissecting room and anatomical museum. Mr. R. Welch exhibited numerous photographs and other objects, notably a series of remarkable primitive vehicles from co. Antrim, which illustrated several stages in the evolution of the Irish jaunting car. Many of the papers read at the meeting will be published in full by the Anthropological Institute either in their Journal or in Man.

\section{PHYSIOLOGY AT THE BRITISH ASSOCIATION.}

PROF. HALLIBURTON, president of the Section, read a paper on the regeneration of nerves, contributed by Dr. Mott and himself. Two opinions existed in regard to the regeneration of nerve-fibres. One set of observers concluded that the new nerve-fibres sprout out from the central stump of the divided nerve-trunk. This was the opinion of by far the larger number of workers. The other opinion was that the new nerve-fibres were of peripheral origin. Those who held the latter view relied almost entirely upon histological evidence. But a strand of cells that looked like a nerve-fibre to the microscope might nevertheless be not physiologically a nerve-fibre, inasmuch as it might be quite unable to be excited as a true nerve-fibre is or to conduct nerve impulses as a nerve-fibre can. These functional performances were the true criteria for nerve-fibres. Among recent 
observers, Howell and Huber, who had used both histological and experimental methods, had arrived at the conclusion that the axis cylinder, the essential portion of a nerve-fibre, had an exclusively central origin; they admitted that the peripheral tissues in which it was embedded were active in preparing and generating a nutritive scaffolding for it. With Dr. Mott he had come to experimental results which, so far as they at present went, confirmed those by Howell and Huber. One experiment they had performed was to divide a large nerve and suture the ends together. After a sufficient length of time had passed, restoration of function occurred, and this was taken as a sign that regeneration had successfully ensued. Then they exposed the nerve-trunk anew. The union of the two ends was then found to have been accomplished, and on testing the nerve it was found to be excitable by faradisation when the stimulus was applied either below or above the point of reunion of the divided trunk. A piece of the nerve-trunk was then excised some little distance below the point of reunion ; on microscopical examination of this, new nerve-fibres were discovered within it. Subsequent to this second operation, the wound was closed up and the animal was finally sacrificed ten days later. When the animal was finally then examined, the nerve both above and below the second section was once more tested for response to electric stimulation. The peripheral piece was then found to have become once more inexcitable. Degeneration had also set in within the fibres of the peripheral piece of the nerve-trunk. Prof. Halliburton urged that this showed that the degenerative process which followed the direction of growth had occurred in a peripheral direction only and had not started at the periphery. Observations were also mentioned indicating that normal functional activity exercised an important influence on the speed and perfection of the process of nerve repair. Paralysis was induced in the arm of the monkey by section of a number of the cervico-brachial afferent spinal roots. By this device, the motor cells of the cord in that region, namely, the cells whence originate the motor nerve-fibres of the limb, are cut off from the influence of all impulses coming to them reflexly from the sensory nerves of the limb itself. A large nerve-trunk in the arm is then divided and the corresponding nerve-trunk of the opposite non-paralysed limb is likewise cut, the latter as a control experiment. Union of the ends of the divided nerves occurred on both sides, but on the side on which the afferent roots had been cut the union was much slower and less perfect, as shown both by histological and by electrical examination of the nerve.

Prof. Schäfer communicated the results of a series of experiments executed with the object of analysing further the mechanism connecting the muscular apparatus with the centres for willed movement having their seat within the brain. He compared the relative effects of transection of the pyramidal tracts and of the ventral columns of the spinal cord. The observations had been made on monkeys. Section of the ventral columns of the spinal cord produced paralysis of volun tary movement in the parts of the body lying behind the seg mental level of the lesion. The descending fibres of the ventral columns of the cord were in the main derived from the cells of the nucleus of Deiters in the bulb, a group of fibres that were, on the other hand, related to the impulses entering the brain from the labyrinth organ, namely, the semicircular canals and the otolith organ. It had been proved by Ewald and others that the destruction of the labyrinth organ entailed diminution and impairment of the "tonus" of the voluntary muscles of the body. Prof. Schäfer proposed to account for the paralysis ensuent upon transection of the ventral spinal columns by the removal of the bracing influence of Deiter's nucleus from the ventral horn cells of the spinal cord, the tonus of muscles being certainly primarily a tonus of the ventral horn cells of the cord. The paralysis produced by section of the ventral columns of the cord would on this explanation be comparable with that described by Sherrington and Mott in the monkey consequent on section of the afferent roots, which seems to take effect by producing loss of tonus in the motor nerve-cells.

A paper on some new features in the intimate structure of the human cerebral cortex was read by Dr. John Turner. His specimens showed (I) a beaded network enveloping the pyramidal cells of the cortex and their dendrites ; (2) an intercellular plexus of nerve-fibrils not previously demonstrated to exist. The preparations demonstrating these points had been made by placing pieces of the brain tissue directly on removal from the body, and without previous hardening or fixing, into a staining solution containing methylene blue and hydrogen peroxide. From this mixture, after a sufficient time had elapsed, the tissue was transferred to a solution of molybdate of ammonia. The tissue was then after this fixation dehydrated, embedded in paraffin and cut into sections. The beaded network is a network, not of neuroglial fibres, but of processes of true nerve-cells. This network loosely invests the pyramidal cells and their dendrites. The network is made up of the finer ramifications of stouter fibres which can be traced from certain pyriform dark cells in the cerebral cortex; these cells are generally small, and no signs of any network can be seen around them. There seem, in fact, in the cortex of the cerebrum to be at least two systems of nerve-cells present, the pyramidal variety, which are pale under the method of examination here employed, and the smaller darkly stained pyriform nerve-cells. These latter possess branches which ramify and form by a fusion a network enveloping the pyramidal cells. Since the network is a true network formed by actual anastomosis, the system of dark cells constitutes a continuum. Dr. Turner urged that in all probability collaterals arising from the axons of the pyramidal cells also joined on to the network. If that were so, all the nerve-cells of the cortex would be practically in organic continuity. He suggested that the differences observed in staining, shape, arrangement, \&c., of the two varieties of cells indicated a difference in function. There was good ground for associating the pyramidal cells with motor functions; he was therefore inclined to ascribe to the dark pyriform cel ls sensory functions. They were in all likelihood, he urged, the bearers and distributors of afferent impulses. This method might therefore afford a means of showing where ingoing currents ended and where outgoing currents started. On this view, however, the impulses must flow in a centrifugal direction in the dendrites of the dark cells and in a centripetal direction in the axons of those cells; this was against the views generally in acceptance which regard the axon as always a cellulifugal conductor and the dendrites as always conducting in a direction toward the perikaryon.

Prof. Schäfer corroborated the description of the microscopical structures described and discovered by Dr. Turner. He suggested, however, that the course of conduction was not cellulifugal in the dendrites of the dark cells. He argued that it was more probable that the nervous pericellular network took up impulses brought by the afferent fibres coming to the cortex in such large numbers from the optic thalamus; that these im. pulses in part were carried through the pyramid cells and in part through the dendrites of the dark cells to the perikarya and axons of these latter.

Dr. Page May communicated a paper upon the movements and innervation of the stomach. His investigation had been an experimental one, and the animals employed had been cats, dogs and monkeys. A short time after taking food, movements of a rhythmic character arise in the muscle of the wall of the organ. These movements are waves of contraction, each of which commences near the œsophageal end of the stomach. The waves succeed each other at a rate of about three times per minute, and they slowly increase in strength as they pass toward the pylories. The contractions have their origin in the wall of the organ itself, because they will continue for half an hour or more after removal of the viscus from the body and its preservation in a bath of warm saline solution. The small ganglia in the wall of the stomach probably coordinate the contractions. Although the gastric contractions are of autocthonous origin, they are subject to control of the central nervous system by means of the vagus nerve, especially of the left vagus nerve. On stimulating the peripheral end of the vagus nerve, the tone of the gastric muscle is usually at once much diminished. Any gastric contractions are usually then abolished. Shortly after this, on the contrary, renewed movements set in, often very vigorous in character, and usually about four times as powerful as the contractions during ordinary digestive activity. Thus the first effect of stimulation of the vagus is inhibition of the gastric tone, the second is increase of tone and augmentation of movement. Stimulation of the central end of the vagus produces a slight inhibitory effect upon the stomach if the other vagus nerve is intact. The splanchnic nerve was not found to exert any influence upon the musculature of the stomach, either in the direction of augmentation or of inhibition. Occasionally some inhibition of gastric movement is excited by the stimulation of the splanchnic, but this not usually; such occasional results are due probably to the vaso-constriction produced by the splanchnic

NO. I 722 , VOL, 66 ] 
stimulation. Anæmia of the stomach experimentally produced by blocking the thoracic aorta cuts short the normal contractions of the organ. The cerebral centres for the gastric movements and tone, which have been described by many observers, notably by Bechterew and Opendowsky, were not found, although diligently searched for. No definite result upon the movements of the stomach seemed to result from any cerebral stimulation.

Prof. Schäfer contributed a communication on the diuretic action of pituitary extracts, based on recent researches by Dr. Magnus, of Heidelberg, and himself. He showed a series of tracings exhibiting by the graphic method the effect that intravenous injection of extract of pituitary body has upon the activity of the kidneys. The epithelial part of the pituitary body yields an extract which causes a marked increase in urinary secretion. This part of the gland had always previously been supposed inert. The diuretic action now proven to be exerted by the gland had, Prof. Schäfer urged, a direct bearing upon the disease called acromegaly, in which the pituitary body was enlarged and diuresis was present.

Prof. Gotch brought forward an experiment upon fatigue and nerve. It had long been held that repeated or excessive activity caused fatigue of nerve-endings, but had no effect upon the fibres which conduct the nervous impulses. Herzen had recently questioned the truth of the above generally adopted view. Herzen stated that after a nerve-trunk had been subjected to repeated stimuli, the subsequent response of the nerve shows signs of impairment when examined by electrical tests. This impairment it had been the object of the present observations to examine, and they showed that the impairment was a change which was confined in its situation to the neighbourhood of the place of the electrodes by which the electric currents used for fatiguing the nerve were applied to the nerve. Were the effect a true fatigue effect, its locus should not be confined to the electrode region, but should be distributed throughout the nerve, because the process of conduction of nerve-impulses occupying the whole length of the nerve, the true fatigue which arose as their after effect must have a similar distribution. The changes which were confined to the immediate neighbourhood of the electrodes by which the long series of "fatigue"-producing currents were introduced were those to which much attention has long been devoted as electrotome. Probably the process involved was one of electrolysis, and certainly its relation to fatigue in the true sense was at most extremely remote. For the experiments the capillary electrometer had been employed; the electric differences studied had been given by the nervous impulse in response to a single induction current.

Dr. Edridge-Green brought forward evidence regarding the distribution in the retina of the photo-sensitive pigment, the visual purple. This pigment belongs to the "rods" only, and is not present in the "cones." Nevertheless, Dr. EdridgeGreen finds that it is present in the central region of the retina, a region in which there are cones only and no rods. On examining the retina of the monkey, when that animal had, in order to increase the amount of visual purple, been kept in the dark for twenty.four hours, the central region of vision, the yellow spot, instead of being free from visual purple was the most purple part of the whole retina. The purple was, however, seen by microscopic examination to be around and not actually in the cones. He advanced the theory that the cones were only sensitive to changes in the visual purple, not to light itself.

Dr. Osborne communicated the results of researches on glycogen carried out in conjunction with Dr. Zobel. Glycogen when hydrolysed by a diastatic ferment gives rise to bodies very similar to those derived from starch. Amongst these is the socalled isomaltose, shown by Brown and Morris to be a mixture of maltose and a dextrin-like body. When acted on by saliva, glycogen gives dextrins, dextrose and maltose.

Dr. C. S. Myers referred to observations on the smallest perceptible musical tone-difference as examined in the people of Scotland and of the Torres Straits. The investigations had been conducted by means of tuning-forks. The least perceptible tone-difference among the children of Murray Island was not widely different from those of the children of Aberdeenshire. But with practice the Aberdeenshire children improved more readily and uniformly. The adult Murray Islanders for the most part failed to detect a semi-tone interval. The average difference of vibration-frequency just distinguishable by the
Adult Murray Islanders was fifteen vibrations per second, whereas for the adult Scotch examined it was nine vibrations.

Dr. Page May gave an excellent demonstration of sections of the brain and of the spinal cord of the camel.

Mr. Barcroft described work dealing with a series of observations on the quantitative estimation of urea.

\section{MAGNETIC WORK OF THE UNITED STATES}

COAST AND GEODETIC SURVEY, OUT-

LINED FOR JULY I, 1902-JUNE 30, 1903.

(a) LAND Magnetic Survey Work.-The determination of the three magnetic elements at 400-500 stations distributed principally in Virginia, New Jersey, Pennsylvania, Ohio, Michigan, Kansas, Nebraska, Texas, Arkansas and Florida.

(b) Magnetic Observatory Work. - The continuous operation of the four magnetic observatories situated at Cheltenham, Maryland ; Baldwin, Kansas ; Sitka, Alaska ; and near Honolulu, Hawaiian Islands ; also the selection of sites and preparations of plans of an observatory in Porto Rico or vicinity, and another in the extreme western part of the United States. [The International Committee on Terrestrial Magnetism and Atmospheric Electricity at the Bristol Conference in 1897 recommended Porto Rico as a suitable and favourable site. The recent magnetic disturbances experienced simultaneously with volcanic eruptions in Martinique will now make the vicinity of Porto Rico an especially important location for a fully equipped magnetic observatory.]

(c) Ocean Magnetic Survey Work.-The inauguration of magnetic work on board ship in connection with regular trips of vessels engaged in coast survey work. [In this connection it is also proposed during the coming winter to make some trial investigations of the distribution of the magnetic elements over the frozen portions of Lakes Michigan, Superior and Huron in the vicinity of the Straits of Mackinac. The necessary observations at shore stations and on islands will be made in the fall and spring.]

(d) Special investigations conducted at the magnetic observatories and at certain educational institutions by persons available as "associate magnetic observers."

(e) At the office at Washington a special effort will be made to bring all computations of field work performed and investigations conducted since July I, I899, up to date and prepare results for publication.

\section{THE "SUDD" OF THE WHITE NILE.}

$A$ RECENT number of the Geographical Journal contains a paper on the "sudd" of the White Nile, by Dr. Edward S. Crispin, explaining the method of opening up the true river bed employed by Major Matthews, who commanded the Sudd Expedition of I9OI-I9O2. The first difficulty is to find the position of the river bed; this is done by probing, the depth suddenly increasing to 15 or 20 feet. Next the top growth, consisting mostly of papyrus, is cut down or burnt ; and it was noted that when the papyrus was fired the fire frequently spread along what was afterwards found to be the true bed of the river. Men are then landed on the cleared surface and the sudd cut along the river banks with saws; next transverse cuts are made, dividing the sudd into blocks of size convenient for the steamer to tear out. The bows of the steamer are run into the block, and the loop of a steel hawser, both ends of which are made fast to the steamer, is passed over the bows and trodden into a trench cut on the surface of the block. The steamer then goes full speed astern, men standing on the hawser to keep it in position, and after a number of trials the block is torn away. The block is then towed clear and cast adrift to float down stream, when it is gradually disintegrated. We reproduce figures illustrating $(a)$ the steamer towing out a block of sudd, showing the men standing round and holding the hawser in position, and (b) the block let go in open water and floating down stream.

The chief growths in the sudd are papyrus and tiger or elephant grass, a kind of bamboo growing to a height of 20 feet or more. Up these climbs a creeper of the convolvulus species. There is also abundance of ambatch and a long

NO. $1 \% 22$, VOL. 66$]$ 